\title{
POTENSI WAKAF TUNAI DALAM MENDORONG PENGEMBANGAN UMKM DI KOTA PEKANBARU
}

\author{
Marina Zulfa ${ }^{1}$ \& Muhammad Arif ${ }^{\mathbf{2}}$ \\ ${ }^{1 \& 2}$ Fakultas Agama Islam (FAI), Universitas Islam Riau (UIR) \\ Email : marinazulfa@fis.uir.ac.id, muhammadarif@fis.uir.ac.id
}

\begin{abstract}
ABSTRAK
Tujuan penelitian ini untuk mengetahui potensi wakaf tunai dalam mendorong pengembangan UMKM di Kota Pekanbaru. Metode yang digunakan adalah metode total sampling yang mana populasi dan sampel berjumlah 5 orang dari UMKM kerajinan rotan di Kota Pekanbaru. Berdasarkan hasil penelitian ini menemukan bahwa potensi wakaf tunai dalam mendorong pengembangan UMKM di Kota Pekanbaru dalam bentuk agama, manfaat wakaf tunai, modal usaha, omset penjualan, keuntungan usaha/laba usaha diminati oleh UMKM perabotan rotan dan kerajinan rotan. Hal ini dapat diketahui banyaknya UMKM di Kota Pekanbaru yang mengembangkan usahanya dengan dana wakaf tunai yang diberikan bantuan oleh pihak pengelola wakaf yang ada di Kota Pekanbaru. Dengan adanya bantuan dana ini mampu mengurangi tingkat penganguran dan kemiskinan di Kota Pekanbaru.
\end{abstract}

Kata kunci : Potensi, Wakaf Tunai, Pengembangan UMKM.

\begin{abstract}
This study aimed at knowing the potency of cash waqf in boosting the MSME development in Pekanbaru city. The method used in this study was a total sampling method, whereby the total for population and sample was 5 people from MSME of rattan crafts in Pekanbaru city. Based on the result of this study, it was stated that the potency of cash waqf in boosting the MSME development in Pekanbaru city, in the form of religion, the advantages of cash waqf, working capital, sales turnover, business profit, was liked by the business sector of rattan furniture and rattan crafts. It could be known by the high number of MSMEs in Pekanbaru city that developed the business using cash waqf funds given by waqf administrators in Pekanbaru city. By the existence of this financial aid, it can decrease the unemployment rate and poverty level in Pekanbaru city.
\end{abstract}

Keywords: Potency, Cash Waqf (Religious Endowment), MSME Development. 


\section{PENDAHULUAN}

Wakaf merupakan instrumen ekonomi Islam yang sudah ada semenjak awal kedatangan Islam. Sepanjang sejarah Islam, wakaf telah menunjukan peran penting dalam mengembangkan kegiatankegiatan sosial, ekonomi dan kebudayaan. Selain itu, keberadaan wakaf telah banyak memfasilitasi para sarjana muslim untuk melakukan riset dan pendidikan, sehingga dapat mengurangi ketergantungan pendanaan kepada pemerintah. Wakaf terbukti telah menjadi instrumen jaminan sosial dalam rangka membantu kaum yang lemah untuk memenuhi hajat hidup, baik berupa kesehatan, biaya hari tua, kesejahteraan hidup, dan pendidikan.

Wakaf tunai bisa dijadikan sebagai salah satu solusi guna mendorong pengembangan UMKM di Kota Pekanbaru. Dari sekian banyak aset wakaf di Kota Pekanbaru, tentu ada yang bernilai tinggi dan berpotensi untuk dikembangkan, terutama aset wakaf tanah yang berada pusat kota. Pemahaman dan pemberdayaan harta wakaf di kalangan umat Islam telah mengalami perubahan yang signifikan, baik dalam tataran paradigma wakaf yang awalnya hanya dipahami sebatas pemanfaatan tempat peribadatan yang berbentuk mesjid, saat ini mulai merambah ke dalam upaya pemanfaatan berbagai barang atau benda yang memiliki muatan ekonomi produktif. Sementara pada tataran praktik wakaf kini mulai dikembangkan ke dalam bentuk pemanfaatan yang bernilai produktif dan sebagai sarana peningkatan ekonomi, seperti wakaf produktif untuk pendidikan, rumah sakit dan lain-lain). Adapun data peruntukan wakaf di kota Pekanbaru tahun 2019 berjumlah 937 buah. Menurut data Badan Pusat Statistik Kota Pekanbaru sesuai dengan sensus penduduk tahun 2015, penduduk Pekanbaru mencapai 1.064.566 jiwa. Angka tersebut memiliki potensi yang cukup besar terhadap penghimpunan wakaf tunai dari masyarakat yang bermukim di Kota Pekanbaru. Wakaf tunai dapat menjadi salah satu solusi dan memainkan perannya sehingga dapat mendorong pengembangan UMKM di Kota Pekanbaru.

\section{TINJAUAN PUSTAKA}

\section{Pengertian Potensi}

Potensi adalah kemampuan yang mempunyai kekuatan untuk dikembangakan melalui usaha-usaha terencana dan terprogram melalui strategi-strategi perencanaan yang tepat agar memperoleh hasil yang maksimal yang sesuai ditargetkan. Sedangkan menurut Prakosa dalam Ardhiansyah et al., (2014) potensi adalah kemampuan dari diri seseorang ataupun yang berhubungan dengan hal-hal lain yang dapat digali bahkan dikembangkan.

Berdasakan kedua definisi potensi diatas dapat disimpulkan bahwa potensi merupakan suatu kemampuan yang berhubungan dengan sesuatu objek yang mempunyai kekuatan, yang dapat digali untuk lebih dikembangkan melalui strategistrategi yang telah terencana untuk mencapai hasil yang maksimal sesuai yang telah ditargetkan. (Majdi, 2007)

\section{Pengertian UMKM}

Usaha kecil Menengah adalah sebuah istilah yang mengacu ke jenis usaha yang memiliki kekayaan bersih paling banyak Rp 200.000.000 tidak termasuk tanah dan bangunan tempat usaha. (Asmita, 2017)

Badan Pusat Statistik menggolongkan menjadi 4 kategori UMKM berdasarkan jumlah tenaga kerja yang dimiliki. Yang pertama adalah industri rumah tangga apabila memiliki tenaga kerja 1 sampai 4 orang, kedua adalah industri kecil dengan jumlah tenaga kerja antara 5 sampai 9 orang, ketiga adalah industri sedang atau menengah apabila memiliki tenaga kerja antara 10 hingga 99 orang, terakhir adalah industri besar apabila memiliki jumlah tenaga kerja lebih dari 100 orang. (Rudianto, 2015)

\section{Pengertian Wakaf}

Secara etimologi, wakaf berasal dari perkataan Arab "Waqf" yang berarti "alHabs". Ia merupakan kata yang berbentuk 
masdar yang pada dasarnya berarti menahan, berhenti atau diam. Menurut UndangUndang No. 41 Tahun 2004, wakaf diartikan dengan perbuatan hukum wakif untuk memisahkan dan/atau menyerahkan sebagian harta benda miliknya untuk dimanfaatkan selamanya atau untuk jangka waktu tertentu sesuai dengan kepentingnnya guna keperluan ibadah dan/atau kesejahteraan umum menurut syariah.

Dari beberapa definisi wakaf tersebut, dapat disimpulkan bahwa wakaf bertujuan untuk memberikan manfaat atau faedah harta yang diwakafkan kepada orang yang berhak dan digunakan sesui dengan ajaran syariah Islam. (M. Zein,2004).

\section{Sejarah dan Perkembangan Wakaf di Indonesia}

dapat $\begin{gathered}\text { Perkembangan } \\ \text { dikatakan }\end{gathered}$ sejalan di $\begin{array}{r}\text { Indonesia } \\ \text { dengan }\end{array}$ perkembangan penyebaran Islam. Pada masa-masa awal penyiaran Islam, kebutuhan terhadap mesjid untuk menjalankan aktivitas ritual dan dakwah berdampak positif, yakni pemberian tanah wakaf untuk mendirikan mesjid menjadi tradisi yang lazim dan meluas di komunitas-komunitas Islam di Nusantara. Seiring dengan perkembangan sosial masyarakat Islam dari waktu ke waktu praktik perwakafan mengalami kemajuan setahap demi setahap. Wakaf merupakan ajaran Islam yang umum dipraktikkan masyarakat. Wakaf untuk mesjid, lembaga pendidikan, pesantren, dan kuburan merupakan jenis wakaf yang paling dikenal oleh masyarakat.

Pada tingkat tertentu, perkembangan wakaf juga dipengaruhi oleh kebijakan perundang-undangan pada masanya. Sejak masa kolonial, aturan wakaf telah ada terkait dengan administrasi dan pencatatan wakaf. Aturan perundang-undangan wakaf tersebut terus berkembang sejalan dinamika perkembangan dan pengelolaan wakaf di lapangan. Dari sini, jumlah dan aset wakaf terus meningkat. Meskipun demikian, peningkatan tersebut tidak disertai dengan upaya peningkatan mutu pengelolaan wakaf, terutama peningkatan mutu sumber daya manusia dan manajemennya. Karena itu, tidak heran mengapa wakaf produktif tidak tumbuh dengan baik. Dalam perjalanannya, sejarah wakaf terus berkembang dan akan selalu berkembang bersamaan dengan laju perubahan zaman dengan berbagai inovasi yang relevan, seperti bentuk wakaf uang, wakaf hak atas Kekayaan Intelektual (HAKI), dan lain-lain. Di Indonesia sendiri, saat ini wakaf kian mendapat perhatian yang cukup serius dengan diterbitkannya UndangUndang No. 41 tahun 2004 tentang Wakaf dan PP No. 42 tahun 2006 tentang pelaksanaannya.

\section{Pengertian Wakaf Tunai}

Wakaf tunai adalah penyerahan hak milik berupa uang tunai kepada seseorang, kelompok orang, atau lembaga nadzir untuk dikelola secara produktif dengan tidak mengurangi atau menghilangkan 'ain asset sehingga dapat diambil hasil atau manfaatnya oleh maukuf alaih sesuai dengan permintaan wakaf yang sejalan dengan syariat Islam. (Soemitra, 2017).

Wakaf uang adalah wakaf dalam bentuk uang yang kemudian dikelola secara produktif oleh nadzir, dan hasilnya dimanfaatkan untuk wakaf. (S. Rusydiana \& Abrista, 2017)

\section{Dasar Hukum Wakaf}

Secara khusus tidak ditemukan nash Al-Qur'an dan Hadis yang secara tegas menyebutkan dasar hukum ibadah wakaf. (Ul-haq, 2018)

Namun, para Ulama mengemukakan beberapa ayat-ayat Al-Qur'an dan Hadis sebagai dasar hukum wakaf, kendati masih mengandung pengertian wakaf secara umum, yaitu antara lain:

\section{Dasar Al-Qur'an :}

Surah Al-Baqarah ayat 261. Artinya: "Perumpamaan (nafkah yang dikeluarkan oleh orang-orang yang menafkahkan hartanya di jalan Allah) adalah serupa dengan sebutir benih yang menumbuhkan tujuh butir, pada tiap-tiap butir seratus biji. 
Allah melipatgandakan (ganjaran) bagi siapa yang dia kehendaki. Dan Allah Maha Luas (kurnia-nya) lagi Maha Mengetahui (Q,S. Al-Baqarah : 261).

Berkaitan dengan ayat di atas, dalam memahami maksud menafkahkan harta di jalan Allah SWT oleh Departemen Agama RI mengatakan bahwa pengertiannya meliputi belanja untuk kepentingan Jihad, pembangunan perguruan tinggi, rumah sakit, usaha penyelidikan ilmiah, dan lain-lain. Kemudian dapat dijelaskan bahwa apabila yang dimaksudkan dengan nafkah, menurut undang-undang wakaf, harta wakaf dapat digunakan untuk sarana wakaf dan kegiatan ibadah, sarana dan kegiatan pendidikan, beasiswa dan kesehatan, bantuan untuk fakir miskin, anak terlantar dan yatim piatu, peningkatan ekonomi umat dan kemajuan kesejahteraan umum.

Tantangan pengelolaan wakaf adalah bagaimana harta benda wakaf tetap terpelihara keabadiannya dan manfaatnya pun mengucur terus-menerus bagi si penerima (mauquf alaih). Untuk itu pengelolaan dan pengembangan harta benda wakaf harus dilakukan secara profesional. (Megawati, 2014)

\section{Rukun dan Syarat Wakaf}

Pada dasarnya rukun dan syarat wakaf adalah: (Sari, 2006)

1. Ada orang yang berwakaf (waqif).

2. Ada harta yang diwakafkan (mauquf).

3. Ada tempat kemana diwakafkan harta itu/tujuan wakaf atau diperuntukkan harta benda wakaf.

4. Ada akad/pernyataan wakaf (sighot) atau ikrar wakaf.

\section{METODE PENELITIAN}

Jenis penelitian ini adalah penelitian deskriptif yaitu jenis penelitian yang disusun dalam rangka memberikan gambaran secara sistematis tentang informasi ilmiah yang berasal dari subjek atau objek penelitian. (Sanusi, 2011) Adapun yang menjadi subjek penelitian ini adalah pengusaha kerajinan rotan beragama Islam di Kota Pekanbaru. Sedangkan yang menjadi objek penelitiannya adalah potensi wakaf tunai. Adapun sebagai populasi pada penelitian ini adalah seluruh pengusaha kerajinan rotan di kota Pekanbaru. Sedangkan Sampel dalam penelitian ini berjumlah 4 pengusaha kerjaninan rotan. Sumber Data adalah data yang diperoleh atau dikumpulkan oleh peneliti secara langsung dari sumber datanya. Untuk mendapatkan data primer, peneliti harus mengumpulkan data primer ini adalah dengan cara penyebaran berupa angket. Metode pengumpulan data penelitian ini adalah observasi, wawancara, kepustakaan, dan dokumentasi.

\section{HASIL DAN PEMBAHASAN}

Hasil wawancara dengan responden akan menunjukkan bagaimana potensi wakaf tunai dalam mendorong pengembangan UMKM kota Pekanbaru. Wawancara dilakukan dengan para pemilik toko Perabot rotan pada sentra kerajinan di Kota Pekanbaru yang terletak di jalan Yosudarsso yakni Ibu Suci Ramadhani pemilik toko Perabot Rotan Kirana, Ibu Time pemilik toko Perabot Rotan USM, Ibu Elsan Naomi Oktariazai pemilik toko Perabot Rotan Farel. Kemudian data disajikan dalam bentuk uraian singkat kedalam masing-masing kategori dan disimpulkan secara kualitatif.

\section{Toko Perabot Rotan Kirana}

Adapun penyajian dari hasil pengumpulan data berdasarkan beberapa dimensi dalam penelitian ini yang dijabarkan sebagai berikut:

\section{Agama}

Agama Islam merupakan agama terbesar yang dianut oleh umat Islam di dunia salah satu ajarannya ialah untuk menjamin kebahagiaan hidup pemeluknya di dunia dan diakhirat yang termaktub dalam Al-Quran dan Hadits. Dari hasil wawancara dengan pemilik toko Perabot Rotan Kirana pada tanggal 04 September 2020 meyatakan bahwa: 
"Agama dan ekonomi memiliki hubungan yang sangat erat karena agama merupakan serangkaian keyakinan, peraturan yag harus di patuhi oleh setiap manusia. Dengan mematuhi dan mengikuti ajaran agama Islam maka akan membawa manusia kepada kebahagiaan dunia juga akhirat. Kami terus berusaha untuk bekerja sesuai dengan aturan agama Islam, dengan seperti itu maka kami dapat hidup lebih tenang”.

Hasil analisis dan kesimpulan penulis menyatakan bahwa toko Perabot Rotan Kirana sudah memahami dan meyakini dan memahami bahwa agama dan ekonomi memiliki hubungan yang sangat erat.

\section{Manfaat Wakaf Tunai}

Wakaf tunai adalah penyerahan hak milik berupa uang tunai kepada seseorang, kelompok orang, atau lembaga nadzir untuk dikelola secara produktif. Dari hasil wawancara dengan pemilik toko Perabot Rotan Kirana pada tanggal 04 September 2020 meyatakan bahwa:

"Saya belum begitu memahami dan mengetahui mengenai wakaf tunai ini, tapi kalau memang dapat diterapkan maka cukup bagus untuk pengembangan dan peningkatan usaha umat, dan besar kemungkinan akan meningkatkan kesejahteraan masyarakat yang beragama Islam”.

Dari hasil observasi dan wawancara maka penulis dampat menarik kesimpulan bahwa wakaf tunai yang jika dikelola dengan baik oleh nadzir yang cerdas dan produktif, maka akan dapat meningkatkan kesejahteraan umat, mengurangi kemiskinan, dan dapat melahirkan wakif (pemberi wakaf) baru. Berdasarkan temuan diatas penulis juga menyimpulkan toko Perabot Rotan Kirana pada awalnya masih kurang memahami mengenai wakaf tunai, hal ini kemungkinan disebabkan oleh masih kurangnya sosialisasi wakaf tunai tersebut, namun jika wakaf tunai ini memang bisa berjalan maka sangat bagus dan dapat membantu para pengusaha untuk mengembangkan usahnya dengan mendapatkan pembiayaan dari wakaf tunai tersebut.

\section{Modal Usaha}

Pengertian modal usaha menurut kamus besar bahasa Indonesia adalah uang yang dipakai sebagai pokok (induk) untuk berdagang, melepas uang, dan sebagainya; harta benda (uang, barang, dan sebagainya) yang dapat dipergunakan untuk menghasilkan sesuatu yang dapat menambah kekayaan.

Dari hasil wawancara dengan pemilik toko Perabot Rotan Kirana pada tanggal 04 September 2020 meyatakan bahwa:

"Berbicara perkara modal, usaha kami ini adalah usaha yang berasal dari orang tua, ya dapat dikatakan ini adalah usaha warisan yang awalnya berlokasi di Padang, setelah saya menikah saya dan suami pergi merantau ke Pekanbaru dan juga mencoba membuka usaha sendiri. Dan pada saat ini usaha saya tetap berjalan walaupun saingan main banyak, saya tetap berusaha berjualan karena hanya inilah kemampuan yang saya miliki bersama suami. Kami belum pernah mengajukan pinjaman pada lembaga keuangan karena kami masih dibantu oleh keluarga yang berada di Padang".

Berdasarkan temuan diatas penulis dapat menyimpulkan bahwa pemilik toko Perabot Rotan Farel sudah mengetahui manfaat jika wakaf tunai ini dapat di alokasikan untuk pemberian pinjaman kepada pengusaha-pengusaha kecil. Mereka menjadi lebih bersemangat dalam menjalankan usahanya bahkan termotivasi untuk terus mengembangkan usahanya karena mereka bebas dari dosa riba, hal ini juga membuat mereka mampu bersaing dengan usaha-usaha sejenis. Pemilik toko juga sudah memahami bahwasanya dana yang dipinjam dari dana wakaf tunai nantinya harus dikembalikan.

\section{Omset Penjualan}

Secara pengertian omset merupakan jumlah uang hasil penjualan barang (dagangan) tertentu selama suatu masa jual. Hasil wawancara yang dilakukan dengan 
pemilik toko Perabot Rotan Farel pada tanggal 04 September 2020 adalah sebagai berikut :

"Adapun usaha yang kami lakukan untuk meningkatkan omzet penjualan yang jika dikaitkan dengan modal adalah dengan menyisihkan keuntungan kami sedikit demi sedikit untuk mengembangkan usaha, meningkatkan hasil produksi dengan berbagai jenis dan bentuk baru dengan modal yang sudah kami kumpulkan tersebut. Kami masih berusaha untuk mandiri dalam mengembangka usaha, dengan dana yang tidak banyak tersebut tentunya penjualan tidak mengalami banyak peningkatan. Namun apabila nantinya kami dapat melakukan pembiayaan dengan dana wakaf tunai tersebut maka kami yakin usaha kami ini nantinya akan sangat berkembang dan tentunya akan meningkatkan omzet penjualan. Jika sudah berkembang sudah tentu kami akan mampu untuk berkompetisi dengan para pengusaha sejenis. Untuk memancing minat calon pembeli kami tidak melakukan banyak hal selain dari menghasilkan produk yang rapi, bersih, dan juga memiliki kwalitas yang baik. Dan yang menjadi harapan kami adalah nantinya kami mendapatkan pijaman modal sehingga dapat memperbnyak jumlah dan jenis produksi toko kami sehingga bnyak calon pembeli yang tertarik untuk membeli produk-produk kami karena ketersediaan kebutuhan calon pembeli yang kami miliki”.

Berdasarkan temuan diatas penulis juga menyimpulkan toko Perabot Rotan Farel tidak melakukan banyak hal untuk peningkatan omset penjualan, tetapi iya memiliki keinginan untuk dapat bersaing dengan usaha-usaha sejenis jika nanti mendapatkan pinjaman dari dana wakaf tunai, untuk meningkatkan omset penjualan mereka akan berusaha mengembangkan usahanya dengan memperbanyak hasil produk dan membuat jenis-jenis yang baru, hal ini bertujuan untuk menarik minat masyarakat, pelanggan atau calon konsumen.

\section{Keuntungan Usaha/Laba Usaha}

Keuntungan usaha atau laba usaha adalah pendapatan dikurangi biaya eksplisit atau biaya akuntansi perusahaan. Laba usaha berbeda dengan laba ekonomi, yaitu pendapatan perusahaan dikurangi dengan biaya eksplisit dan biaya implisit.

Dari hasil wawancara dengan pemilik toko Perabot Rotan Kirana pada tanggal 04 September 2020 meyatakan bahwa:

"Dalam hal meningkatkan laba usaha kami masih tidak begitu banyak melakukan berbagai hal, kami hanya berusaha untuk terus memproduksi kerajinan rotan dengan cara membuat variasi-variasi baru pada setiap produk yang kami hasilkan. Apabila kami mendaptkan pinjaman modal usaha tanpa bunga seperti dari wakaf tunai maka kami yakin usaha kami akan jauh lebih berkembang bahkan akan sangat memungkinkan keuntungan yang kami dapatkan akan terus mengalami peningkatan. Tak hanya itu, kami juga yakin akan mampu bersaing dengan pengusaha-pengusaha kerajinan rotan yang lain".

Dari temuan diatas dapat disimpulkan bahwa dengan terbatasnya modal yang dimiliki maka tidak banyak yang dapat dilakukan oleh pemilik usaha, dengan modal yang minim maka pemilik usaha hanya dapat melakukan variasi-variasi baru untuk setiap produknya. Apabila dana wakaf tunai ini dapat dialokasikan pada pembiayaan kepada para pengusaha maka akan berpengaruh pada berkembangnya usaha tersebut dan secara tidak langsung juga berpengaruh terhadap meningkatnya keuntungan usaha/laba usaha. Tidak hanya sampai disitu, apabila para pengusaha mendapatkan pembiayaan untuk penambahan modal usaha, maka dapat menjadikan usaha tersebut terus bertahan dan memiliki kemampuan untuk bersaing dengan usaha-usaha sejenis.

\section{Toko Perabot Rotan USM}

Adapun penyajian dari hasil pengumpulan data berdasarkan beberapa 
dimensi dalam penelitian ini yang dijabarkan sebagai berikut:

Agama

Dari hasil wawancara dengan pemilik toko Perabot Rotan USM pada tanggal 04 September 2020 meyatakan bahwa:

"Islam sebuah keyakinan yang bertuhankan Allah SWT, dengan kitab suci Al-quran yang didalamnya mengandung berbagai aturan untuk kebaikan dan kebahagiaan dunia dan akhirat. Agama sudah tentu memiliki hubungan dengan kegiatan ekonomi, karena dalam agama banyak peraturan-peraturan yang harus di ikuti seperti jangan berbuat curang, bohong dan lain sebagainya”.

Berdasarkan temuan diatas, penulis dapat mengambil kesimpulan bahwasanya pengusaha kerajinan rotan toko Perabot Rotan USM sudah memahami tentang Agama Islam, yang mana agama Islam merupakan serangkaian keyakinan, peraturan serta tuntunan moral untuk setiap aspek kehidupan manusia di muka bumi, agama yang mampu menuntun manusia menuju kebahagiaan dunia dan akhirat. Namun masih disayangkan toko tersebut dalam bermuamalah ekonomi masih terikat dengan riba pada saat membutuhkan dana tambahan, hal ini dikarenakan pemahamannya yang menyatakan masih sulitnya mendapatkan pinjaman dari lembaga keuangan syariah. Namun dalam pelaksanaan jual beli toko ini sudah berusaha untuk mengikuti aturanaturan dalam agama Islam.

\section{Manfaat Wakaf Tunai}

Dari hasil wawancara dengan pemilik toko Perabot Rotan USM pada tanggal 04 September 2020 meyatakan bahwa:

"Jika kata-kata wakaf saya paham dan sudah mengetahui, wakaf ini banyak direalisasikan atau diperuntukkan kepada tanah perkuburan, mesjid dan juga sekolah. tetapi untuk wakaf tunai saya baru kali ini mengetahuinya, jadi belum banyak hal yang saya ketahui dan pahami mengenai wakaf tunai ini, apalagi yang namanya pembiayaan dari dana wakaf tunai. Saya belum pernah melakukan pinjaman atau pembiayaan pada dana wakaf tunai ini".

Berdasarkan temuan yang penulis dapatkan dari hasil wawancara tersebut maka penulis dapat menyimpulkan bahwa toko Perabot Rotan USM sangat setuju dan menyambut baik jika wakaf tunai ini nantinya dialokasikan untuk pembiayaan pada usaha-usaha mikro terkhusus pada usaha yang sedang ditekuninya, karena akan dapat mengembangkan usaha dan dapat mengurangi jumlah kemiskinan di Indonesia.

\section{Modal Usaha}

Dari hasil wawancara dengan pemilik toko Perabot Rotan USM pada tanggal 04 September 2020 meyatakan bahwa:

"Untuk mendapatkan modal usaha atau tambahan modal usaha dari wakaf tunai saya belum pernah tahu. Pembiayaan atau pinjaman yang bebas dari riba yang saya ketahui hanya ada pada bank syariah. Jika saya mendapatkan pinjaman dari wakaf tunai yang bebas dari riba ini dan dalam pengurusannya tidak sulit dan merepotka tentunya membuat saya gembira, saya dapat mengembangkan usaha saya, karena selama ini saya masih menyisihkan sedikit demi sedikit dari keuntungan untuk menjadi modal tambahan dalam usaha saya ini”.

Dari temuan diatas maka penulis dapat mengambil kesimpulan bahwa toko Perabot Rotan USM juga sangat antusias dan semangat dalam mengembangkan usahanya apabila mendapatkan dana pinjaman dari wakaf tunai yang diperuntukkan untuk modal usaha atau tambahan modal usahanya. Beliau juga termotivasi untuk terus mengembangkan usaha bila nantinya mendapatkan dana untuk pengembangan usahanya dan mempunyai harapan yang besar dengan adanya program wakaf tunai yang dialokasikan untuk pembiayan usaha dapat membebaskan mereka dari dosa riba.

\section{Omset Penjualan}

Secara pengertian omset penjualan merupakan jumlah uang hasil penjualan 
barang (dagangan) tertentu selama suatu masa jual. Hasil wawancara yang dilakukan dengan pemilik toko Perabot Rotan USM pada tanggal 04 September 2020 adalah sebagai berikut:

Kami tidak begitu banyak melakukan usaha untuk meningkatkan laba, selain karena keterbatasan modal kami juga kesulitan untuk mendapatkan modal tambahan untuk pengembangan usaha, kami hanya bisa terus memproduksi kerajinan rotan dengan jumlah standar dan membuat variasi-variasi baru pada setiap produk yang kami hasilkan. Apabila kami mendaptkan pinjaman modal usaha tanpa bunga seperti dari wakaf tunai maka kami yakin usaha kami akan jauh lebih berkembang bahkan akan sangat memungkinkan keuntungan yang kami dapatkan akan terus mengalami peningkatan. Tak hanya itu, kami juga yakin akan mampu bersaing dengan pengusahapengusaha kerajinan rotan yang lain, apabila kami sudah mampu bersaing, kami yakin dapat meningkatkan keuntungan usaha atau laba usaha kami".

Dari temuan diatas dapat disimpulkan bahwa dengan terbatasnya modal yang dimiliki maka tidak banyak yang dapat dilakukan oleh pemilik usaha, dengan modal yang minim maka pemilik usaha hanya dapat melakukan variasi-variasi baru untuk setiap produknya. Apabila dana wakaf tunai ini dapat dialokasikan pada pembiayaan kepada para pengusaha maka akan berpengaruh pada berkembangnya usaha tersebut dan secara tidak langsung juga berpengaruh terhadap meningkatnya keuntungan usaha/ laba usaha. Dengan kemampan bersaing dengan para pengusaha sejenis maka toko Perabot rotan USM ini yakin dapat meningkatkan keuntungan usaha atau laba dari usaha yang sedang dijalani.

\section{Toko Perabot Rotan Azil}

Adapun penyajian dari hasil pengumpulan data berdasarkan beberapa dimensi dalam penelitian ini yang dijabarkan sebagai berikut:

\section{Agama}

Dari hasil wawancara dengan pemilik toko Perabot Rotan Azil pada tanggal 04 September 2020 meyatakan bahwa:

"Agama Islam adalah sebuah ajaran yang bertuhankan Allah, dengan kitab suci Al-Quran, yang memiliki rukun iman dan rukun Islam, nabi Muhammad yang menjadi teladan. Berbagai aturan tertuang jelas didalam Al-Quran dengan segala macam balasan, kita sebagai umat Islam wajib mematuhi segala perintah dan menjauhi segala larangan-Nya agar mendapat kebahagian dunia dan akhirat. Sebagaimana disebutkan tadi, bahwasanya didalam Al-Quran sudah sangat jelas mengatur segala urusan, termasuk didalamnya ekonomi. Sebagai umat Islam dan agar jiwa kami juga tenang maka kami berusaha untuk berbuat sesuai dengan aturan-aturan, seperti tidak menipu, jujur, menepati janji dan sebagainya, untuk sampai saat ini kami belum melakukan kredit atau pembiayaan pada bank, kami masih bekerjasama dengan keluarga apabila membutuhkan dana".

Dari temuan diatas, penulis menyimpulkan bahwa toko Perabot Rotan azil sudah memahami bahwasanya agama dan kegiatan ekonomi memiliki hubungan yang sangat erat, agama Islam merupakan serangkaian keyakinan, peraturan serta tuntunan moral untuk setiap aspek kehidupan manusia dimuka bumi. Suatu ajaran yang membawa ketenangan jiwa dan menuntun manusia menuju kebahagiaan dunia dan akhirat. Dalam bermuamalah toko Perabot Azil juga sudah berusaha untuk bertindak sesuai dengan tutunan Islam.

\section{Manfaat Wakaf Tunai}

Dari hasil wawancara dengan pemilik toko Perabot Rotan Azil pada tanggal 04 September 2020 meyatakan bahwa:

"wakaf yang saya ketahui adalah pemberiaan sesuatu yang masih bisa dimanfaatkan kepada masyarakat seperti tanah yang diwakafkan untuk kuburan, untuk mesjid dan lain sebagainya. Untuk wakaf tunai saya masih belum begitu mengetahui 
dan baru ini mendengarnya, begitu juga dengan wakaf tunai yang dananya bisa digunakan untuk memberikan pinjaman kepada masyarakat atau para pengusaha kecil untuk mengembangkan usahanya. Jika wakaf tunai ini memang dapat digunakan untuk memberikan pinjaman kepada pengusaha kecil atau pedagang-pedagang kecil maka hal ini dapat meningkatkan kesejahteraan pengusaha-penugasa kecil, para pedagang kecil yang kesulitan mencari pinjaman untuk tambahan modal usahanya, sehingga perekonomian kami bisah lebih baik. Apabila wakaf tunai ini dikelola dengan maksimal maka saya yakin dapat mengurangi kemiskinan dan besar kemungkinan juga nantinya jika dilakukan pembinaan terhadap para pengusaha yang mendapatkan pinjaman tersebut maka akan lahir para wakif baru (pemberi wakaf)".

Dari temuan diatas, maka penulis dapat menyimpulkan bahwasanya toko Prabaot Rotan Azil masih memiliki informasi mengenai wakaf yang terbatas, karena Wakaf yang masih di pahami selama ini oleh pemilik toko tersebut masih terbatas wakaf tanah. Setelah mendapatkan informasi pada saat pelaksanaan wawancara mengenai wakaf tunai ini, responden memiliki kepercayaan bahwasanya wakaf tunai ini apabila dikelola dengan baik maka dapat meningkatkan kesejahteraan umat, mengarahkan perekonomian para pengusaha kecil menuju kearah yang lebih baik, memiliki potensi untuk mengurangi kemiskinan dan juga akan melahirkan para wakif baru (pemberi wakaf).

\section{Modal Usaha}

Dari hasil wawancara dengan pemilik toko Perabot Rotan Azil pada tanggal 04 September 2020 meyatakan bahwa:

"Pembiayaan wakaf tunai untuk pengembangan usaha tanpa riba tentunya dapat membebaskan kami dari dosa riba, namun sampai saat ini kami belum pernah mendapatkan pinjaman atau pembiayaan tersebut, apabila kami mendapatknnya tentu kami akan lebih bersemangat dalam mengembangkan usaha kami dengan memperbanyak jenis dan unit produk kami, sehingga setiap konsumen datang kami dapat menyediakan produk yang mereka cari”.

Berdasarkan temuan diatas penulis dapat menyimpulkan bahwa pemilik toko Perabot Rotan Azil adanya pemahaman mengenai pinjaman dana untuk pengembangan usaha dari wakaf tunai dapat membuat mereka bebas dari dosa riba. Tingginya motivasi untuk mengembangkan usaha apabila terpenuhinya kebutuhan dalam hal modal untuk pengembangan usahanya dan juga memahami bahwasanya dana yang dipinjam juga harus dikembalikan.

\section{Omset Penjualan}

Secara pengertian omset merupakan jumlah uang hasil penjualan barang (dagangan) tertentu selama suatu masa jual. Hasil wawancara yang dilakukan dengan pemilik toko Perabot Rotan Azil pada tanggal 04 September 2020 adalah sebagai berikut:

"Cara kami meningkatkan omset penjualan tidak begitu kelihatan, kami hanya memproduksi seperti biasanya dengan target yang sudah menjadi rata-rata. Untuk modal yang dikaitkan dengan peningkatan omset, kami juga tidak begitu memaksakan harus memiliki modal yang besar".

Berdasarkan temuan diatas penulis juga menyimpulkan toko Perabot Rotan Azil masih membutuhkan modal tambahan untuk pengembangan usahanya agar dapat bersaing dengan usaha-usahaa sejenis. Dan pemilik toko juga memiliki keyakinan apabila memiliki modal untuk pengembangan maka toko Perabot Rotan Azil ini nantinya meningkatkan omset penjualannya di setiap bulan dikarenakan akan tertariknya calon pembeli untuk memilih dan membeli produk yang sudah mereka hasilkan.

\section{Keuntungan Usaha/Laba Usaha}

Dari hasil wawancara dengan pemilik toko Perabot Rotan Azil pada tanggal 04 September 2020 meyatakan bahwa: 
"Sebagaimana yang sudah saya sampaikan tadi, bahwasanya tidak begitu kelihatan, dan keuntungan yang kami dapatkan juga sifatnya masih rata-rata pada setiap bulannya, namun pada masa pendemi ini penjualan kami jauh menurun karena sepinya pelanggan dan calon pembeli yang datang ke toko kami. Jika program ini bisa terlaksana dan jalan, maka bisa menjadi kabar gembira untuk kami semua karena bisa mendapatkan modal tambahan tanpa riba, kami dapat menghasilkan banyak produk dan dengan berbagai jenisnya, kami bisa bersaing, dan tentunya dapat meningkatkan keuntungan untuk usaha kami".

Dari temuan diatas dapat disimpulkan bahwa toko Perabot Rotan Azil jika mendapatkan pinjaman dari dana wakaf tunai maka akan menambah banyaknya produk dan jenis-jenis produk yang dihasilkannya, adanya keyakinan dapat ikut bersaing dengan para pengusaha sejenis dan dapat meningkatkan keuntungan usaha tiap bulanya.

\section{Toko Perabot Rotan Farel}

Adapun penyajian dari hasil pengumpulan data berdasarkan beberapa dimensi dalam penelitian ini yang dijabarkan sebagai berikut:

\section{Agama}

Dari hasil wawancara dengan pemilik toko Perabot Rotan Kirana pada tanggal 04 September 2020 meyatakan bahwa:

"Agama Islam adalah agama yang dapat membawa kebahagiaan dunia dan akhirat. Agama dan ekonomi saya rasa memiliki keterkaitan karena agama mempunyai aturan-aturan yang jelas untuk semua sisi kehidupan. Dalam kegiatan usaha rotan ini kami berusaha untuk mengikuti aturan-aturan agama Islam dengan tidak berbuat berbagai kecurangan dan kebohongan".

Hasil analisis dan kesimpulan penulis menyatakan bahwa toko Perabot Rotan Farel sudah memahami bahwasanya agama
Islam adalah serakaian keyakinan, peraturan serta tuntunan moral untuk setiap aspek kehidupan manusia dimuka bumi, agama yang akan membawa kebahagiaan didunia dan akhirat. Dalam kegiatan usahanya sudah berusaha untuk bermuamalah sesuai dengan tuntunan Islam.

\section{Manfaat Wakaf Tunai}

Wakaf tunai adalah penyerahan hak milik berupa uang tunai kepada seseorang, kelompok orang, atau lembaga nadzir untuk dikelola secara produktif. Dari hasil wawancara dengan pemilik toko Perabot Rotan Farel pada tanggal 04 September 2020 meyatakan bahwa:

"Menurut saya wakaf adalah sebuah ibadah yang dilakukan oleh seorang muslim dengan memberikan sesuatu yang ia miliki untuk diberikan kepada orang banyak. Contohnya tanah yang diberikan untuk dipergunakan sebagai tanah perkuburan, mesjid dan sekolah. Apabila sudah diwakafkan maka harta tersebut tidak bisa lagi dialihkan atau diperjual belikan kepada orang lain. Untuk wakaf tunai saya masih belum begitu memahami bahkan baru kali ini mengetahui bahwasanya wakaf itu juga ada wakaf tunai".

Dari temuan diatas maka penulis dapat menarik kesimpulan bahwasanya pemilik toko Perabot Rotan Farel masih belum mengetahui dan memahami mengenai wakaf tunai, pemahamannya masih terbatas pada wakaf secara umum dan lebih fokus kepada wakaf tanah yang diperuntukkan untuk pembangunan mesjid, perkuburan dan sekolah. Pemilik toko beranggapan jika ia nanti dapat pinjaman dari wakaf tunai maka ia dapat merubah kehidupan ekonominya menjadi lebih baik, wakaf tunai ini jika dialokasikan untuk memberikan pinjaman untuk tambahan modal usaha maka dapt meningkatkan kesejahteraan umat Islam, mengurangi kemiskinan dan pengangguran. 


\section{Modal Usaha}

Dari hasil wawancara dengan pemilik toko Perabot Rotan Kirana pada tanggal 04 September 2020 meyatakan bahwa:

"Berbicara perkara modal, usaha kami ini adalah usaha yang berasal dari orang tua, ya dapat dikatakan ini adalah usaha warisan yang awalnya berlokasi di Padang, setelah saya menikah saya dan suami pergi merantau ke Pekanbaru dan juga mencoba membuka usaha sendiri. Dan pada saat ini usaha saya tetap berjalan walaupun saingan main banyak, saya tetap berusaha berjualan karena hanya inilah kemampuan yang saya miliki bersama suami”.

Berdasarkan temuan diatas penulis dapat menyimpulkan bahwa pemilik toko Perabot Rotan Farel sudah mengetahui manfaat jika wakaf tunai ini dapat di alokasikan untuk pemberian pinjaman kepada pengusaha-pengusaha kecil. Mereka menjadi lebih bersemangat dalam menjalankan usahanya bahkan termotivasi untuk terus mengembangkan usahanya karena mereka bebas dari dosa riba, hal ini juga membuat mereka mampu bersaing dengan usaha-usaha sejenis. Pemilik toko juga sudah memahami bahwasanya dana yang dipinjam dari dana wakaf tunai nantinya harus dikembalikan.

\section{Omset Penjualan}

Secara pengertian omset merupakan jumlah uang hasil penjualan barang (dagangan) tertentu selama suatu masa jual. Hasil wawancara yang dilakukan dengan pemilik toko Perabot Rotan Farel pada tanggal 04 September 2020 adalah sebagai berikut:

"Sejauh ini tidak banyak yang kami
lakukan untuk meningkatkan omset
penjualan, kami masih mengikuti rata-rata
penjualan kami disetiap bulannya. Menurut
saya, pembiayaan atau pinjaman dari wakaf
tunai ini dapat berdampak pada peningkatan
omset penjualan, karena dana tersebut dapat

dijadikan sebagai penambahan modal untuk pengembangan usaha".

Berdasarkan temuan diatas penulis juga menyimpulkan toko Perabot Rotan Farel tidak melakukan banyak hal untuk peningkatan omset penjualan, tetapi iya memiliki keinginan untuk dapat bersaing dengan usaha-usaha sejenis jika nanti mendapatkan pinjaman dari dana wakaf tunai, untuk meningkatkan omset penjualan mereka akan berusaha mengembangkan usahanya dengan memperbanyak hasil produk dan membuat jenis-jenis yang baru, hal ini bertujuan untuk menarik minat masyarakat, pelanggan atau calon konsumen.

\section{Keuntungan Usaha/ Laba Usaha}

Dari hasil wawancara dengan pemilik toko Perabot Rotan Farel pada tanggal 04 September 2020 meyatakan bahwa:

"Sama halnya dengan peningkatan omset penjualan, kami masih tidak banyak melakukan sesuatu untuk meningkatkan laba, yang kami lakukan hanya terus berproduksi seperti biasanya, dan terus berusaha untuk mempertahankan dan meningkatkan kualitas. Keuntungan yang kami dapatkan perbulannya selalu rata-rata, terkadang naik dan juga terkadang turun dan sifatnya juga tidak drastis. Saya rasa jika program ini jalan dan di kelola dengan profesional maka dapat meningkatkan jumlah keuntungan pada tiap bulannya”.

Dari temuan diatas dapat disimpulkan bahwa dengan pemilik toko Perabot Rotan Farel dalam hal peningkatan keuntungan usaha atau laba usaha masih tidak begitu kelihatan, keuntungan yang didapatkan tiap bulannya masih hampir sama pada tiap bulannya. Ia juga berpendapat jika modal terpenuhi maka usaha dapat terus berkembang dan akan dapat menaikkan keuntungan usaha/ laba usahanya.

\section{KESIMPULAN}

Toko Perabot Rotan Kirana, masih kurang memahami mengenai wakaf tunai, hal ini kemungkinan disebabkan oleh masih kurangnya sosialisasi wakaf tunai tersebut. 
Toko Perabot Rotan USM, toko tersebut dalam bermuamalah ekonomi masih terikat dengan riba pada saat membutuhkan dana tambahan, hal ini dikarenakan pemahamannya yang menyatakan masih sulitnya mendapatkan pinjaman dari lembaga keuangan syariah. Toko Perabot Rotan Azil, responden memiliki kepercayaan bahwasanya wakaf tunai ini apabila dikelola dengan baik maka dapat meningkatkan kesejahteraan umat, mengarahkan perekonomian para pengusaha kecil menuju ke arah yang lebih baik, memiliki potensi untuk mengurangi kemiskinan dan juga akan melahirkan para wakif baru (pemberi wakaf). Toko Perabot Rotan Farel, Pemilik toko beranggapan jika ia nanti dapat pinjaman dari wakaf tunai maka ia dapat merubah kehidupan ekonominya menjadi lebih baik, wakaf tunai ini jika dialokasikan untuk memberikan pinjaman untuk tambahan modal usaha maka dapat meningkatkan kesejahteraan umat Islam, mengurangi kemiskinan dan pengangguran.

\section{DAFTAR PUSTAKA}

Ardhiansyah, D., Rahayu, S. M., \& Husaini, A. 2014. Analisis Potensi Pajak Hotel dan Pajak Restoran dan Kontribusinya terhadap Pendapatan Asli Daerah (PAD)-Studi Kasus pada Dinas Pendapatan Asli Daerah Kota Batu Tahun 2011-2015. Jurnal Administrasi Bisnis, 14(1), 1-8.

Asmita, Nila. 2017. Prospek Pemasaran Usaha Kecil Menengah Kerajinan Rotan di Pekanbaru Perspektif Ekonomi Islam. Jurnal Al-Amwal, $6(2)$.

M. Zein,Satria Effendi. 2004. Problematika Hukum Keluarga Islam Kontemporer, cet.I. Kencana. Jakarta.

Majdi, Udo Yamin Efendi. 2007. Quranic Quotient. Qultum Media. Jakarta.

Megawati, Devi. 2014. Pengelolaan dan Pengembangan Wakaf Produktif di Kota Pekanbaru. Jurnal Hukum Islam, 4(2).
Rudianto, $\quad 2015$.

Pengembangan UMKM antara

Konseptual dan Pengalaman Praktis. Gajah Mada University Press.

S. Rusydiana, Aam \& Devi, Abrista. 2017. Analisis Pengelolaan Dana Wakaf Uang di Indonesia: Pendekatan Metode Analytic Network Process (ANP). Jurnal Wakaf dan Ekonomi Islam, 10(2). p 115-133.

Sanusi, Anwar. 2011. Metode Penelitian Bisnis. Salemba Empat. Jakarta.

Sari, Elsi Kartika. 2006. Pengantar Hukum Zakat dan Wakaf. PT. Grasindo. Jakarta.

Soemitra, Andri. 2017. Bank dan Lembaga Keuangan Syariah. Prenadamedia Grup. Jakarta.

Ul-haq, Hilma Bahtiar. 2018. Analisis Pengelolaan Wakaf Uang oleh nazhir di Yayasan Badan Wakaf Sultan Agung Semarang. Undergraduate (S1) thesis, UIN Walisongo. 